\title{
Kontrol Motor AC 3 Fasa Pada Peluncur Peluru Kendali
}

\author{
Rosyidin Sufyani ${ }^{1}$, Syafruddin $R^{2}$, Givy Devira Ramady ${ }^{3}$, Andrew Ghea Mahardika ${ }^{4}$, Decy Nataliana ${ }^{5}$ \\ 1,2,3,4 Sekolah Tinggi Teknologi Mandala, Bandung, Indonesia, Alamat: Soekarno-Hatta St No.597, Bandung 40284, \\ Telepon: (022) 7301738 Website: https://www.sttmandalabdg.ac.id \\ ${ }^{5}$ Institute Teknologi Nasional, Bandung, Indonesia, Alamat: Jl. PH.H. Mustofa No.23, Bandung, 40124, Telepon: (022) 7272215 \\ E-mail:syafruddinr@yahoo.com
}

\begin{abstract}
Abstrak - Latar belakang penelitian adalah kebutuhan kontrol motor ac 3 fasa diperlukan untuk mendapatkan posisi yang presisi, dimana motor ac 3 phasa dengan daya antara $0,25 \mathrm{~s} / \mathrm{d} 1 \mathrm{kw}$ bila digunakan untuk membuat gerak posisi yang presisi, cukup sulit, karena adanya momen inersi, saat diam diperintah jalan proses waktu mulai dari kecepatan nol ke kecepatan nominal cukup lama, kira kira 1 s/d 2 detik, begitu juga saat dari putaran normal diperintah berhenti kekecepatan nol proses waktu berhenti berkisar 2 s/d 3 detik, sedangkan yang kita inginkan waktu mulai 0,5 detik dan waktu berhenti 0,75 detik, berhenti tepat di posisi yang diperintahkan. Permasalahan ini sangat menggangu didalam membuat kontrol sistem yang lain, karena waktu yang cukup lama saat mulai dan saat berhenti, proses ini akan berulang setiap saat sesuai modulasi sinyal kontrol yang diterima oleh sistem kontrol motor, sedang waktu operasi sistem yang diinginkan hanya 30 detik dalam mengikuti target biar tidak hilang di bidikan kamera, mulai dari awal target didapat s/d akhir proses saat menyalakan tombol penyalaan, seperti yang digunakan dalam mengontrol peluncur peluru kendali. Waktu diproses peluncur hanya ada sekitar beberapa menit, untuk pencarian, penguncian dan penyalaan, kalau tidak objek yang mau di kunci akan hilang dari pengamatan.
\end{abstract}

Kata kunci: presisi, kontrol, kecepatan, tepat, modulasi.

\begin{abstract}
The background of the research is the need for 3 phase ac servoposition is needed to obtain a precise position, where the 3 phase ac motor with a power between 0.25 to $1 \mathrm{kw}$ when used to make precise position movements, is quite difficult, because of the moment of inertia, when silent governed the way the starting time process from zero speed to nominal speed is quite long, about 1 to 2 seconds, as well as when from normal rotation commanded to stop zero speed the process of stopping time ranges from 2 to 3 seconds, whereas we want starting time 0.5 seconds and stop time 0.75 seconds stop right in the position ordered. This problem is very disturbing in making other system controls, because the time is long enough in the starting time and stoping time, and this process will repeat every time according to the modulation of the control signal received by the motor switching system, while the operating time of the desired system is only 30 seconds in following the target so as not to disappear in the camera shot, starting from the target start is obtained until the end of the process when turning on the firing button, as used in controlling the missile launcher. The launcher's processing time is only about a few minutes, for searching, locking and firing, otherwise the object to be locked will disappear from observation.
\end{abstract}

Keywords: precise, control, speed, precise, modulation.

\section{PENDAHULUAN}

Kebutuhan kontrol motor ac 3 fasa pada peluncur peluru kendali diperlukan untuk mendapatkan posisi yang presisi, dimana motor dengan daya antara $0,25 \mathrm{~s} / \mathrm{d} 1 \mathrm{kw}$ bila digunakan untuk membuat gerak posisi yang presisi cukup sulit, karena adanya momen inersi, saat diam diperintah jalan proses waktu mulai dari kecepatan nol ke kecepatan nominal cukup lama, kira kira $1 \mathrm{~s} / \mathrm{d} 2$ detik, begitu juga saat dari putaran normal diperintah berhenti kekecepatan nol proses waktu berhenti berkisar 2 s/d 3 detik, sedangkan yang diinginkan waktu mulai 0,5 detik dan waktu berhenti 0,75 detik, berhenti tepat di posisi yang diperintahkan dan setiap saat selalu dikoreksi jika terjadi kelebihan dan kekurangan dari posisi yang diperintahkan. Permasalahan ini sangat menggangu didalam membuat kontrol sistem 
yang lain, karena jika waktu yang digunakan cukup lama saat mulai dan saat berhenti, karena proses ini akan berulang setiap saat sesuai modulasi ${ }^{[1]}$ sinyal kontrol yang diterima oleh penyalaan motor, sedang waktu operasi sistem yang diinginkan hanya 30 detik, seperti penggunaanya pada peluncur peluru kendali dalam mengikuti target biar tidak hilang di bidikan kamera, mulai dari target didapat s/d akhir proses saat menyalakan tombol penyalaan, seperti yang digunakan dalam sistem kontrol. Waktu diproses peluncur hanya ada sekitar beberapa menit, untuk pencarian, mengunci dan penyalaan, kalau tidak objek yang mau di kunci akan hilang dari pengamatan, karena kecepatan objek sekitar $600 \mathrm{~m} / \mathrm{s}$, dengan harapan kecepatan manuper peluncur saat merancangnya sudah diperhitungkan, disesuaikan dengan kecepatan target tersebut dengan sarat keceptan peluncur bisa mengikuti target kemanapun arahnya.

Dalam merancang kontrol motor ac 3 fasa untuk mendapatkan posisi yang presisi pada peluncur peluru kendali tentu kita pelajari contoh yang ada bagai mana cara kerja mekanikalnya dan terjemahkan dalam flowchart, fisik, matematik, selanjutnya buat program sesuai bahasa yang disukai, tidak memaksakan setiap penelitian harus menyiapkan dari awal semua infrastrukturnya, cukup disesuaikan dengan infrastruktur yang kita punyai, lakukan modifikasi sesuai kebutuhan, karena software dan hardware saat ini bisa dibuatkan interface nya, sehingga apa yang sudah baku di dunia global bisa dipanggil melalui interface, termasuk juga mekanikalnya bisa dibuatkan interface nya yang lebih dikenal dengan jointing system.

Pengembangan prototipe kontrol motor ac 3 fasa pada peluncur peluru kendali merupakan bahagian penting dari sistim peluncur peluru kendali, karena nilai presisi dari gerak 3 dimensi dalam koordinat bola untuk membidik dan mengunci target sangat ditentukan presisi atau tidaknya sistem kontrol motor ac 3 fasanya.

Kontrol motor ac 3 fasa pada peluncur peluru kendali merupakan bahagian dari komponen pengembangan senjata pemusnah massal yang sudah masuk penelitian dan pengembangan jangka panjang program senjata bangsa, dan saatnyalah untuk memulai dari sisi peneliti perguruan tinggi, karena masalah Negara dengan penduduk 269 juta orang tahun 2019. Luas wilayah Indonesia yang meliputi daratan dan lautan seluruhnya $7.081 .369 \mathrm{~km}^{2}$ (KM persegi). Luas daratannya 1.904.569 KM persegi. luas lautannya 5.076.800 KM persegi. Panjang pantai nya $\pm 81.497 \mathrm{~km}$ atau lebih dari dua keliling bumi di ekuator ( keliling bumi $40.000 \mathrm{~km}$ ), maka dari itu mengembangkan bahagian dari sistem peluru kendali berupa kontrol motor ac 3 fasa pada peluncur peluru kendali, merupakan kebutuhan yang sangat urgent buat Negara dalam hal defence dan offence.

\section{LANDASAN TEORI}

Pengembangan kontrol motor ac 3 fasa untuk mendapatkan posisi yang presisi pada peluncur peluru kendali yaitu merobah tegangan $d c$ ke $a c$ dengan mengatur tegangan dan frekwensi output yang dipakai untuk mengontrol motor induksi ac 3 phasa. Ada beberapa tipe pengembangan kontrol motor ac 3 fasa untuk mendapatkan posisi yang presisi pada peluncur peluru kendali diantaranya pengembangan kontrol motor ac 3 fasa untuk mendapatkan posisi yang presisi pada peluncur peluru kendali dengan SVPWM ( Space Vektor Pulse Width modulation $)^{[2,3,4,5]}$.

Untuk dapat menjelaskan SVPWM mari kita lihat gb.1 dibawah ini. Perhatikan beban motor induksi 3 fasa baik itu hubungan belitannya bintang atau delta, yang di suplai dari saklar S1,S2,S3 seperti pada gambar. Syarat saklar S1,S2,S3 saat keatas bernilai satu, saat kebawah bernilai nol, ini bertujuan biar tidak ada terjadi hubungan pendek lengan atas dengan lengan bawah. Saat S1 keatas, transistor Q1 nyala, Q0 padam dan saat S1 kebawah transistor Q1 padam, Q0 nyala, terus saat S2 keatas, transistor Q3 nyala, Q2 padam dan saat S2 kebawah transistor Q3 padam, Q2 nyala begiitu juga saat S3 keatas, transistor Q5 nyala, Q4 padam dan saat S3 kebawah transistor Q5 padam, Q4 nyala. Dari penjelasan diatas kita dapat menyusun saklaar S1,S2,S3 dalam dua variasi nilai yaitu 1 atau 0 . Dengan menyusun S1,S2,S3 secara permutasi 2, didapat hasil sebanyak 8 susunan dipandang sebagai vektor fungsi penyalaan transistor antara lain: V0(000), V1(100), V2(110), V3(010), V4(011), V5(001), V6(101), V7(111) seperti table 1. berikut.

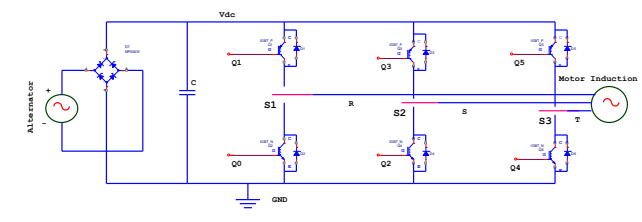

Gb.1 Blok diagram mikrokontroler SVPWM

Table 1. Algoritma penyalaan SVPWM

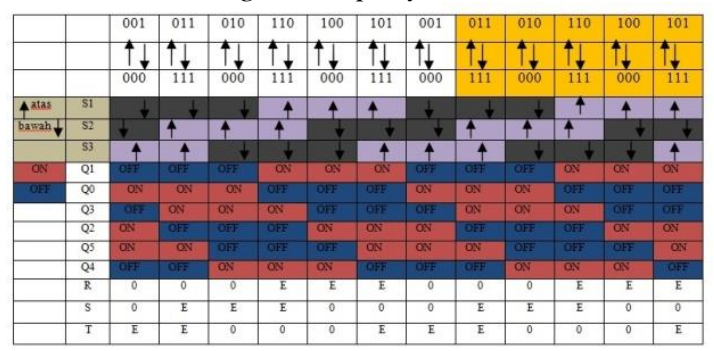

Dari table 1. diatas kita bisa gambar ulang transistor jembatan ac 3 fasa dalam koordinat cartesian seperti gb. 2 berikut.

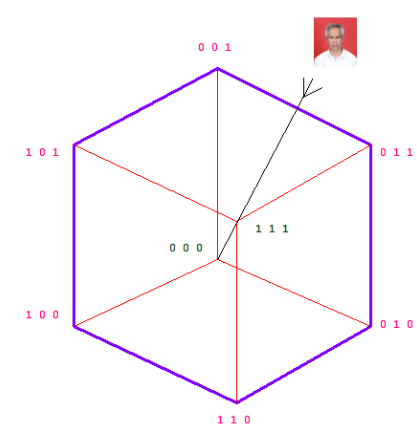

Gb.2 Transistor jembatan ac 3 fasa dalam ruangan 
Selanjutnya bila jembatan ac 3 fasa di pandang seperti gb. 2 maka untuk menyalakan jembatan ac 3 fasa dalam 1 sektor dalam ruangan koordinat cartesian maka dapat digambarkan vektor yang dibangkitkan seperti gb. 3 berikut.

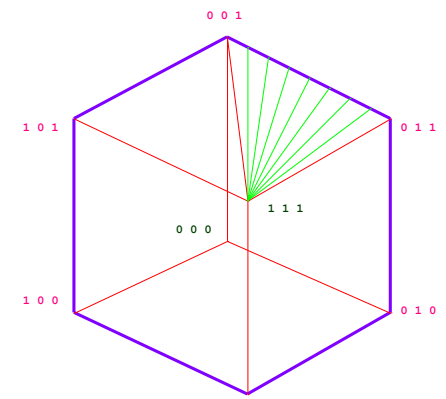

Gb.3 Vektor jembatan ac 3 fasa dalam ruangan di sector 6

Sedangkan untuk menyalakan jembatan ac 3 fasa dalam satu siklus $360^{\circ}$ dalam ruangan koordinat cartesian maka dapat digambarkan vektor yang dibangkitkan seperti gb. 4 berikut.

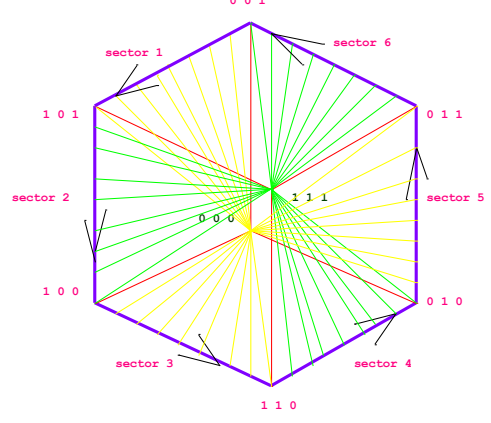

Gb.4 Vektor jembatan ac 3 fasa satu siklus $360^{\circ}$

Dari gb.4 diatas dapat disederhanakan untuk menyalakan jembatan ac 3 fasa dalam ruangan koordinat cartesian untuk 1 siklus $360^{\circ}$ penyalaan maka dapat digambarkan vektor yang dibangkitkan seperti gb. 5 berikut yang dikenal sebagai SVPWM

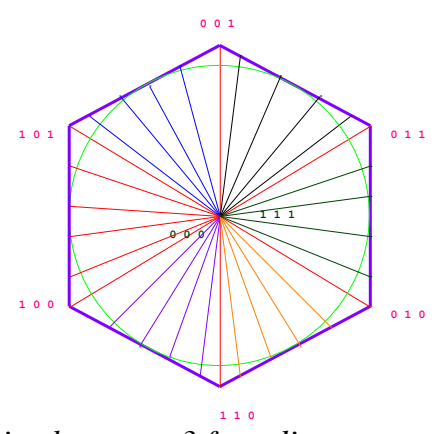

Gb.5 Vektor jembatan ac 3 fasa di ruangan atau SVPWM

Keuntungan dari SVPWM adalah sangat ekonomis dan praktis untuk dipakai pada motor induksi ac 3 fasa. Disamping itu jika pembangkitan sinyal SVPWM dilakukan secara digital akan didapatkan langkah sistem kerja yang lebih pendek yang akan mengurangi noise. Perancangan kontrol motor ac 3 fasa untuk mendapatkan posisi yang presisi pada peluncur peluru kendali dengan cara SVPWM memakai mikro kontroler memberikan beberapa keuntungan yaitu mudah untuk diprogram $^{[6]}$ rangkaian schematic dan $p c b$ akan lebih sederhana. Untuk mengurangi atau mengeliminir harmonisa didalam sistem daya, beberapa metode sudah dikembangkan orang dan menggunakannya lebih praktis. Metode SVPWM digunakan untuk membangkitkan filter daya aktif. Filter daya aktif yang dibangun dari $S V P W M$ dapat diprogram dengan mikrokontroler. Didalam penelitian ini menggunakan microcontroller yang mudah mendapatkannya di pasar lokal dan pada waktu yang bersamaan, kontrol motor ac 3 fasa untuk mendapatkan posisi yang presisi pada peluncur peluru kendali beroperasi sebagai filter aktif menyuplai jaringan dengan arus $a c$ sebagai kompensasi dalam jumlah yang sama dengan arus harmonisa yang diproduksi beban non linear.

Prinsip dalam teorema Space Vektor PWM(SVPWM) didasarkan pada kenyataan bahwa hanya ada 8 langkah kombinasi penyalaan untuk menjalankan jembatan ac 3 fasa, Dasar sistem penyalaan kontrol motor ac 3 fasa untuk mendapatkan posisi yang presisi pada peluncur peluru kendali seperti yang ditunjukan gb.4, gb.5 atau gb.8. Dua langkah SV0 dan SV7 berhubungan dengan short circuit, sementara enam langkah yang lain dianggap vektor dalam bidang $\mathrm{x}-\mathrm{y}$. Besaran nilai fasa maksimum dari masing masing 6 vektor adalah:

$$
\text { Vfasa maksimum }=\frac{2}{3} * V d c
$$

Vkawat kawat maksimum $=\sqrt{3} *$ Vfasa maksimum

Vkawat kawat maksimum $=\sqrt{3}\left(\frac{2}{3} * V d c\right)$
Vkawat kawat maksimum $\left.=\left(\frac{2}{\sqrt{3}}\right) * V d c\right)$

Modulasi indek atau rasio amplitudo didefenisiskan sebagai :

$$
\begin{aligned}
& \left.m=V d c * \cos 30^{\circ} / V d c\right) \\
& \left.m=V d c *\left(\frac{\sqrt{3}}{2}\right) / \mathrm{Vdc}\right) \\
& m=\sqrt{3} / 2
\end{aligned}
$$

Vektor tegangan ini merupakan fungsi waktu, tegangan rata rata dapat dihitung dengan menjumlahkan vektor dalam satu periode penyalaan. Untuk 5 sektor yang lain dihitung dengan cara yang sama. Penjumlahan secara geometrik yang ditunjukan gb.8, untuk setiap periode switching sebesar $\Delta T$. Vektor VS memiliki nilai ril dan imajiner berhubungan dengan $\mathrm{F}=20 \mathrm{kHz}$,

$$
T s=1 / F
$$

seperti yang ditunjukan gb.8. Vektor dalam ruangan dibagi dalam 6 sektor setiap sektornya $60^{\circ}$. setiap sektor dibangun oleh dua vektor. Vektor V0 dan V7 adalah vektor dengan amplitudo nol ada dititik nol hexadiagonal. Resultan VS adalah akibat penyalaan SVPWM. Untuk implementasi secara digital dari SVPWM. Disini penyalaan pada ferkwensi tinggi $\left(\mathrm{F}_{\mathrm{pwm}}\right)$, Frekwensi ini cukup tinggi $(>20 \mathrm{kHz})$ dimana 
sudah diluar audio noise akibat penyalaan. Pengambilan Fpwm sebagai waktu sampling Ts untuk Vs, dimana

$\mathrm{TS}=\frac{1}{\mathrm{Fpwm}}$

Ada beberapa teknik variasi penyalaan untuk membangkitkan VS dari VO,V1,V2,V3, V4,V5,V6,V7. Merujuk pada gb.8, secara matematik dapat ditunjukan oleh persamaan

$V S=\left[\frac{T 0}{T S} * V 0\right]+\left[\frac{T 1}{T S} * V 1\right]+\left[\frac{T 2}{T S} * V 2\right]+\left[\frac{T 3}{T S} * V 3\right]+$

$\left[\frac{T 4}{T s} * V 4\right]+\left[\frac{T 5}{T s} * V 5\right]+\quad\left[\frac{T 6}{T s} * V 6\right]+\left[\frac{T 7}{T s} * V 7\right]$

$\mathrm{TS}=\mathrm{T} 0+\mathrm{T} 1+\mathrm{T} 3+\mathrm{T} 4+\mathrm{T} 5+\mathrm{T} 6+\mathrm{T} 7$

Variabel T0,T1,..., T7 adalah waktu nyala yang berhubungan dengan pernyataan SVPWM dan TS waktu sampling nya. Ketika SVPWM mengikuti pola penyalaan: 1-2-3-4-5-6-12....., ini dikenal dengan algoritma kontrol PWM 6 step. Algoritma PWM 6 step ini lebih mudah diimplementasikan dibandingkan dengan algoritma kontrol yang lain. Algorima kontrol PWM 6 step dapat membangkitkan tegangan 3 fasa line to line lebih besar dari Vdc nya sendiri.

\section{SVPWM (Space Vector Pulse Wide Modulation)} switching rule

Untuk mengimplementasikan SVPWM algoritma, aturan penyalaan berikut di implementasikan :

- Trajektori dari SVPWM harus lingkaran,

- Hanya satu penyalaan per kondisi transisi,

- Tidak boleh lebih dari 3 penyalaan dalam satu TS,

- Kondisi akhir dari satu sampling harus menjadi kondisi awal untuk sampling berikutnya.

Aturan ini membantu dalam membatasi proses penyalaan, dan dari itu, akan mengurangi rugi rugi penyalaan. Juga, akan mempertahankan simetri dalam bentuk gelombang penyalaan pada output SVPWM untuk menekan lebih kecil Total Harmonic Distortion(THD). Jika SVPWM algoritma ini di implementasikan, memakai aturan penyalaan ini, ini disebut SVPWM konvensional. Didalam menjalankan motor ac 3 fasa sebagai pengatur posisi, untuk mendapatkan posisi yang persis dalam waktu yang cepat sesuai dengan perintah yang diinginkan, secara mekanik motor tersebut harus memiliki karakteristik putaran terhadap waktu seperti gb.6 berikut. Disini diharapkan akselerasi putaran motor dari mulai bergerak ke putaran nominal harus cepat sekitar 0,5 detik waktu yang dibutuhkan, untuk deakselerasi juga harus cepat sekitar 0,75 detik waktu yang dibutuhkan. Sedangkan untuk presisi, dimana motor berhenti diharapkan berhenti tepat pada posisi yang diperintahkan diatur oleh sistim kontrolnya.

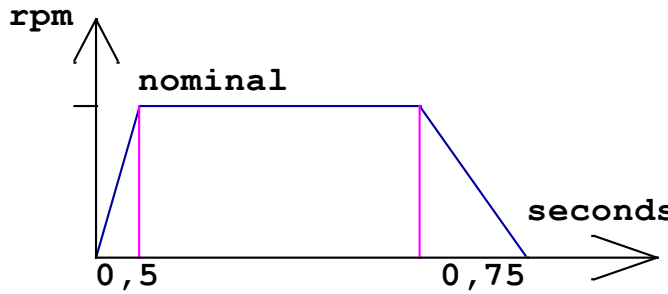

Gb.6 Mulai dan berhenti motor ac 3 fasa

Selanjutnya gerak sistim peluncur peluru kendali merupakan gerak tiga dimensi dalam koordinat bola, seperti yang ditunjukan arah anak panah pada gb.7. Dimana gerak meja peluncur dalam arah sumbu $\varnothing$, dan peluncur dalam arah sumbu theta.

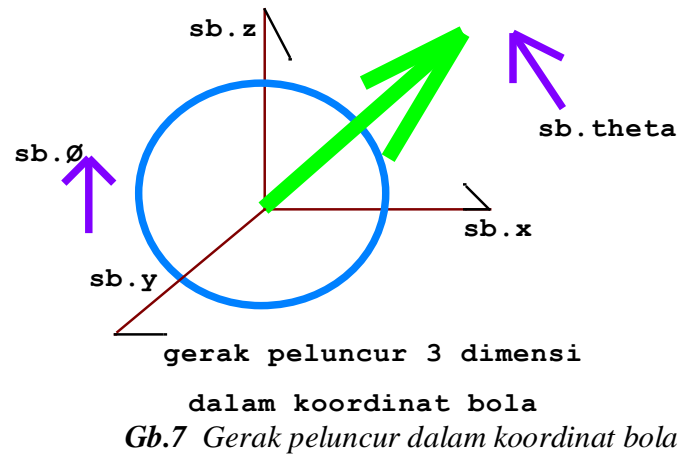

Untuk memudahkan analisa penyalaan jembatan ac 3 fasa, perhatikan gb. 9 berikut, dimana sektor 1 digambar ulang dalam koordinat kartesian bidang $\mathrm{x}-\mathrm{y}$. Dengan mengatur waktu penyalaan TA,TB dan T0/7 di sektor 1 didapatka vektor resultan VS disektor 1 .

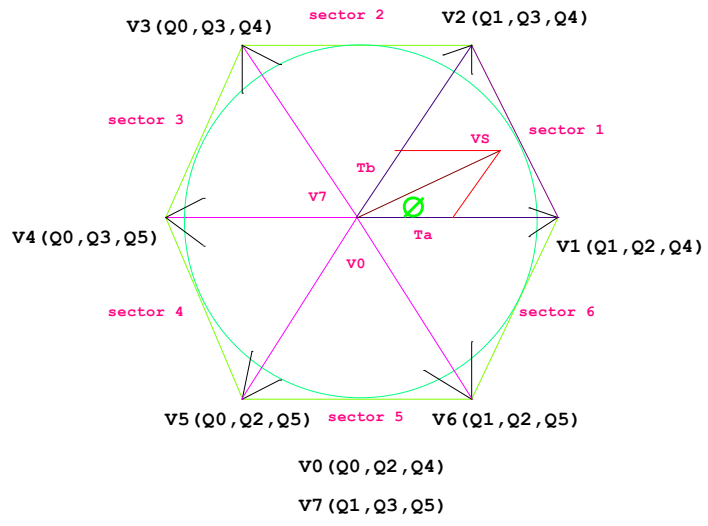

Gb.8 Space Vector Hexagon

Berikut untuk mendapatkan vektor yang dibangkitkan di ruangan setiap saat dalam 1 siklus $360^{\circ}$, mari kita lihat gb.8 diatas. Untuk membangkitkan vektor tegangan disektor 1, jembatan ac 3 fasa cukup dinyalakan vektor fungsi penyalaan transistor di sector 1 bidang V0(000), V1(100), V2(110). Proses penyalaan sesuai gb.9 ,besaran vektor resultan yang didapat sesuai dengan persamaan (8) dan vektor hasilnya seperti yang ditunjukan gb.9. Untuk sektor 2 sampai dengan sektor 6 dilakukan hal yang sama. 


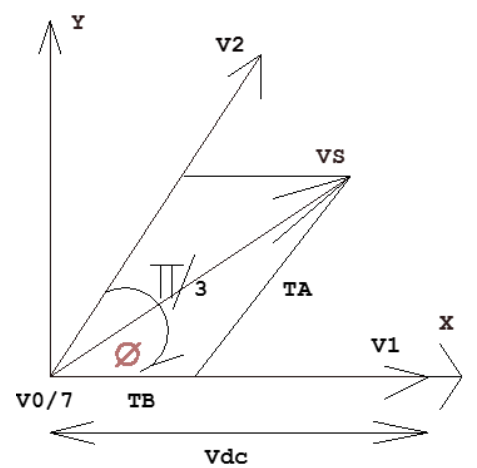

Gb.9 Vektor Vs di sector 1

Dengan meperhatikan gb.9 maka didapat :

$V S=[T A / T s * V 1]+[T B / T s * V 2]+[(T 0 / 7) / T s *$ $V 0 / 7]$

$$
\mathrm{TS}=\mathrm{TA}+\mathrm{TB}+\mathrm{T} 0 / 7
$$

Berikut ini proses penyalaan jembatan ac 3 fasa persektor dapat dilihat gb. 10 berikut, dimana penyalaan disektor 1 selalu simetris, dimulai dan diakiri divektor yang sama, untuk sektor 2, 3, 4, 5 dan sektor 6 dilakukan dengan cara yang sama.

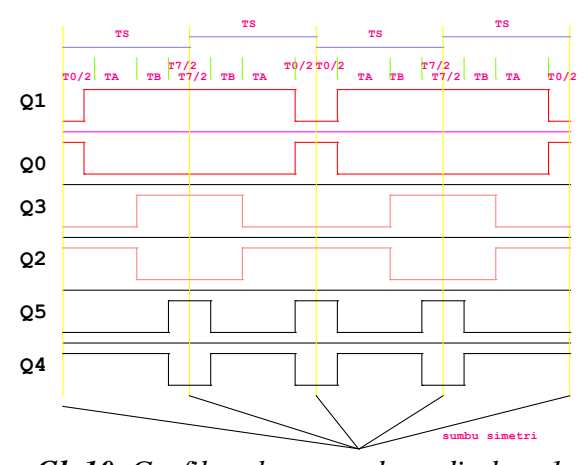

Gb.10 Grafik waktu penyalaan disektor 1

Dari uraian diatas semua, dapat dibuat proses siklus waktu penyalaan jembatan ac 3 fasa berdasarkan lokasi tegangan VS, dan juga dapat dilihat pembebanan siklus penyalaan masing masing fasa untuk tiap sektor seperti table 2 berikut.

TABLE 2. Siklus waktu penyalaan jembatan ac 3 fasa berdasarkan lokasi tegangan Vs

\begin{tabular}{|c|l|l|l|}
\hline $\begin{array}{c}\text { Sek } \\
\text { tor } \\
\text { No. }\end{array}$ & $\begin{array}{c}\text { Siklus } \\
\text { penyalaan } \\
\text { fasa } \mathrm{R}\end{array}$ & $\begin{array}{c}\text { Siklus } \\
\text { penyalaan } \\
\text { fasa S }\end{array}$ & $\begin{array}{c}\text { Siklus } \\
\text { penyalaan } \\
\text { fasa } \mathrm{T}\end{array}$ \\
\hline 1 & $\mathrm{~T} 0 / 2$ & $\mathrm{~T} 0 / 2+\mathrm{TA}$ & $\mathrm{TS}-\mathrm{T} 0 / 2$ \\
\hline 2 & $\mathrm{~T} 0 / 2+\mathrm{TB}$ & $\mathrm{T} 0 / 2$ & $\mathrm{TS}-\mathrm{T} 0 / 2$ \\
\hline 3 & $\mathrm{TS}-\mathrm{T} 0 / 2$ & $\mathrm{~T} 0 / 2$ & $\mathrm{~T} / 2+\mathrm{TA}$ \\
\hline 4 & $\mathrm{TS}-\mathrm{T} 0 / 2$ & $\mathrm{~T} / 2+\mathrm{TB}$ & $\mathrm{T} 0 / 2$ \\
\hline 5 & $\mathrm{~T} 0 / 2+\mathrm{TA}$ & $\mathrm{TS}-\mathrm{T} 0 / 2$ & $\mathrm{~T} 0 / 2$ \\
\hline 6 & $\mathrm{~T} 0 / 2$ & $\mathrm{TS}-\mathrm{T} 0 / 2$ & $\mathrm{~T} 0 / 2+\mathrm{TB}$ \\
\hline
\end{tabular}

Kemandirian teknologi di bidang kontrol motor ac 3 fasa untuk mendapatkan posisi yang presisi pada peluncur peluru kendali akan mengurangi tingkat ketergantungan terhadap komponen impor, dan tentu dengan harapan produk yang dihasilkan secara ekonomi akan lebih murah sebagai dampak ekonomis pemanfaatan hasil dalam negeri.

Kontribusi terhadap sektor lain yang sangat urgent yaitu dapat membantu meningkatkan kemampuan dibidang ilmu pengetahuan dan teknologi .

Dalam hal kontrol motor ac 3 fasa untuk mendapatkan posisi yang presisi pada peluncur peluru kendali memiliki batasan sebagai berikut : Hanya mengembangkan bahagian kontrol motor ac 3 fasa yaitu bahagian kontrol.

Sehubungan batasan diatas maka pengembangan kontrol motor ac 3 fasa juga harus lebih presisi karena yang dibidik bergerak dengan kecepatan tinggi, untuk itu peneliti perlu cari dan baca literature literature yang berhubungan dengan kontrol motor ac 3 fasa pada peluncur peluru kendali presisi tinggi, diantaranya kontrol motor $a c \quad 3$ fasa Tamagawa, Yaskawa, dari sana peneliti cari tahu lebih dalam lagi prinsip pembuatan sinyal kontrol penyalaan rangkaian elektronik kontrol motor ac 3 fasa.

Kontrol motor ac 3 fasa pada peluncur peluru kendali sendiri merupakan motor ac 3 fasa yang dipasang kontrol untuk mengendalikan geraknya sesuai dari keinginan pembuat kontrolnya, disini penulis menginginkan kontrol motor ac 3 fasa itu dikendalikan oleh inputan sinyal perintah dari luar ${ }^{[7]}$, kontrol motor ac 3 fasa akan berhenti sesuai sinyal perintah yang diberikan, untuk mengarah kesasaran yang dituju.

\section{METODOLOGI PENELITIAN}

Secara sederhana dapat dilihat alur penelitian dari kontrol motor ac 3 fasa untuk mendapatkan posisi yang presisi pada peluncur peluru kendali seperti gb.11 berikut: 


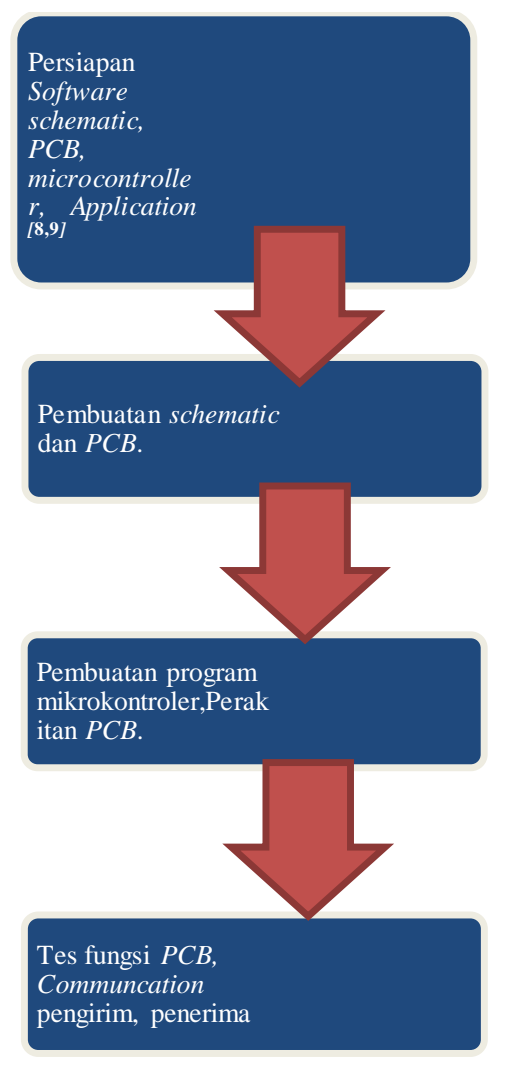

Gb.11 Alur penelitian

Untuk lebih memperjelas metodologi penelitian ini, sesuai dengan alur penelitian gb.11, berikut peneliti coba membuat metoda penelitian selanjutnya berupa flowchart pengolahan sinyal seperti yang ditunjukan gb.12 berikut: Saat kontrol sudah diberi tegangan: suplai kontroler, tegangan radio, tegangan penyalaan transistor daya, tegangan $d c$ jembatan ac 3 fasa, maka kontrol langsung jalan dan selalu menunggu perintah dari luar berupa posisi target, setiap ada perintah langsung diolah untuk dibandingkan dengan posisi akhir yang sudah ada yaitu berupa delta posisi. Nilai delta posisi berupa bilangan negatif atau positif, bila negatif memanggil subrotin kiri dan posistif memanggil subrotin kanan, selanjutnya mengambil masukan dari feedback encoder, dari dua data ini yaitu masukan feedback dan masukan perintah dilakukan perhitungan, hasil perhitungan ini disimpan sebagai posisi akhir, dan hasil perhitungan yang sama merupakan sinyal perintah ke motor, karena sinyal ini masih kecil, dilakukan penguatan dan pengolahan secara Transistor Transistor Logic(TTL), setelah itu sinyal akan menyalakan transistor transistor daya jembatan ac 3 fasa, dan program kembali menunggu perintah selanjutnya, program baru akan berhenti jika ada perintah berhenti berupa mematikan suplai kontroler atau tombol reset ditekan untuk restarting.

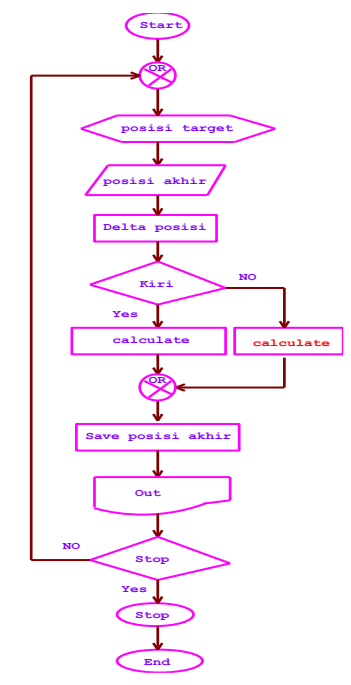

Gb.12 Flowchart pengolahan sinyal

Berikut adalah aplikasi kontrol motor ac 3 fasa pada peluncur peluru kendali yang ada dipasaran, dimana sebagai sumber penggerak tiga dimensi di launcher digunakan motor ac 3 fasa, seperti yang ditunjukan gb.13 berikut.

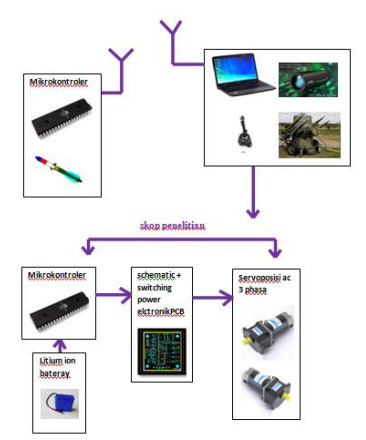

Gb.13 Aplikasi kontrol motor ac 3 fasa pada peluncur peluru kendali

Metode penelitian yang digunakan yaitu metode perancangan dan membuat prototipe, pengujian prototipe, pengambilan data uji prototipe serta analisis hasil pengujian yang dikenal dengan metoda sebab akibat kwantitatif(causal). Hasil uji dikatakan berhasil jika sinyal yang dikirim dari CPU/microcontroller sesuai dengan format yang dikirim, akan memrintahkan kontrol motor $a c$ 3 fasa pada peluncur peluru kendali berhenti pada posisi yang diperintahkan. Perintah $\mathrm{Tx}$ didapat dari inputan penelitian lain, perintah ini akan diulang dengan frequensi $26 \mathrm{~Hz}$ atau perioda TS $=(1 / 26 \mathrm{~Hz})=1 / 26$ detik. Nilai ini merupakan koordinasi dengan gerak mekanik kontrol motor ac 3 fasa untuk menghindari waktu tunggu CPU/microcontroller dan hilangnya data selama satu siklus dari mulai s/d berhenti motor ac 3 fasa $^{[10]}$. 


\section{HASIL DAN PEMBAHASAN}

\subsection{HASIL}

Berikut hasil Timing chart switching Space vector PWM kontrol motor ac 3 fasa gb.14, skematik rangkaian gb.15, pcb gb.16 dan hasil pengukuran tabel.2.

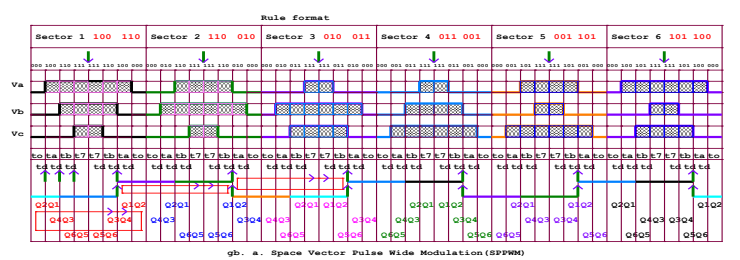

Gb.14 Timing chart switching Space vector PWM ${ }^{[11]}$

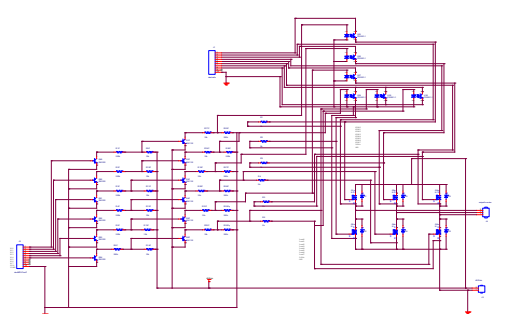

Gb.15 Schematic

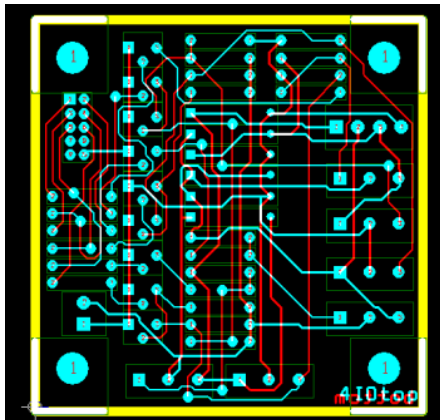

Gb.16 $P C B$

Tabel 3. Hasil Pengukuran.

\begin{tabular}{|c|c|c|c|c|}
\hline $\begin{array}{c}\text { No } \\
.\end{array}$ & Perintah Tx & Penerima Rx & Sesuai & $\begin{array}{c}\text { Tidak } \\
\text { sesuai X }\end{array}$ \\
\hline 1 & $0 \times 22$ & $0 \times 22$ & $\sqrt{ }$ & \\
\hline 2 & $0 \times 28$ & $0 \times 28$ & $\sqrt{ }$ & \\
\hline 3 & $0 \times 30$ & $0 \times 30$ & $\sqrt{ }$ & \\
\hline 4 & $0 \times 32$ & $0 \times 32$ & $\sqrt{ }$ & \\
\hline 5 & $0 \times 34$ & $0 \times 34$ & $\sqrt{ }$ & \\
\hline 6 & $0 \times 36$ & $0 \times 36$ & $\sqrt{ }$ & \\
\hline 7 & $0 \times 38$ & $0 \times 38$ & $\sqrt{ }$ & \\
\hline
\end{tabular}

\subsection{PEMBAHASAN}

Hasil yang didapat sesuai dengan apa yang diharapkan. Sedangkan untuk menjaga tegangan sumber komponen stabil dan sekaligus sebagai filter dipasang kapasitor elektrolit paralel dengan sumber tegangan komponen tiap pcb.

\section{SIMPULAN}

Hasil siap untuk diaplikasikan di lapangan, untuk mengontrol motor ac 3 fasa sebagai kontrol posisi. Timing chart switching Space vector PWM gb.14 memberikan kemudahan dalam membuat kontrol motor ac 3 fasa, hasil tegangan output line to line 3 fasa yang lebih besar dari tegangan input $d c$ nya. Keuntungan dari SVPWM adalah sangat ekonomis dan praktis untuk dipakai pada motor induksi ac 3 fasa. Disamping itu jika pembangkitan sinyal SVPWM dilakukan secara digital akan didapatkan langkah sistem kerja yang lebih pendek yang akan mengurangi noise.

\section{KEPUSTAKAAN}

[1] Antoine, R., A Flexible Realtime Simulation Platform Dedicated to Embedded Rocket Engine Control Systems Development and Testing, 7th European Conference for Aeronautics and Space Sciences (EUCASS), DOI:10.13009/EUCASS2017-1, 2017.

[2] Rakesh, P., VF Control of 3-Phase Induction Motor Using Space Vector Modulation, Microchip Technology Inc., AN955, 1-26. (2005)

[3] Ramady, G.D., Sistem Monitoring Power Baterai Bluetooth Beacon Menggunakan Labview, Jurnal Online Isu Teknologi Sekolah Tinggi Teknologi Mandala, 13, 2, 45-50. (2018)

[4] Pei, Y., Biswas, S., Fussell, D.S., Pingali, K., An Elementary Introduction to Kalman Filtering, Austin: University of Texas, 1-11. (2017)

[5] Isık, M.F., Cetin, E., Aykul, H., and Bayram, H., AC Servo Motor Speed and Position Control Using Particle Swarm

Optimization (PSO), Hittite Journal of Science and Engineering, Hitit University, Corum, Turkey, 2, 2, 159-164. (2015)

[6] Hidayat, R., Smart Key Implementation for BTS Gate Door Based on the Internet of Things, The $1^{\text {st }}$ International Conference on Computer Science and Engineering Technology, Muria Kudus University, 25 ${ }^{\text {th }}$ October 2018.

[7] Syafruddin, Pengembangan Prototipe Sistem Kontrol pada Transmiter Peluru Kendali, Jurnal Online Isu Teknologi Sekolah Tinggi Teknologi Mandala, 14, 1, 42-48. (2019)

[8] Åström, K.J., Advances in PID Control, Department of Automatic Control, Lund University. (2018) https://intranet.ceautomatica.es/sites/default/files/upload/13/files/Ad vancesInPIDControl_KJA.pdf

[9] Bindu, R., Tuning of PID Controller for DC Servo Motor using Genetic Algorithm, International Journal of Emerging Technology and Advanced Engineering, 2, 3, 310-314. (2012)

[10] Sukandi, G.K., Pengembangan Prototipe Sistem Kontrol pada Receiver Peluru Kendali, Jurnal Online Isu Teknologi Sekolah Tinggi Teknologi Mandala, 14, 1, 22-28. (2019)

[11] Kenjoe, T., Support Power Electronic with CPU, Shin Go Denshi Shoe Kata, Dai(2) Kata, 202, 204. (1991) 